\title{
COMUNICAÇÃO
}

\section{COLORAÇÃO DE NÚCLEOS DE ESPOROS E HIFAS DO COGUMELO Agaricus blazei}

\author{
CLÁUDIA REGINA GONTIJO LABORY ${ }^{1}$ \\ EUSTÁQUIO SOUZA DIAS ${ }^{2}$ \\ LISETE CHAMMA DAVIDE ${ }^{2}$ \\ ROSANE FREITAS SCHWAN ${ }^{2}$ \\ INAJÁ MARCHIZELI WENZEL ${ }^{3}$
}

\begin{abstract}
RESUMO - Com o objetivo de se estudar o comportamento nuclear durante o ciclo sexual do cogumelo Agaricus blazei, técnicas de coloração e a utilização de fluorocromos foram testadas, visando a uma padronização metodológica para estudos citogenéticos futuros. Das técnicas avaliadas neste trabalho (método de Feulgen, coloração com Giemsa e fluorescência-DAPI), a colora-
\end{abstract}

ção com Giemsa e o fluorocromo DAPI apresentaram os melhores resultados para evidenciar núcleos. O corante Giemsa permitiu a visualização de compartimentos multinucleados. Com o DAPI, não foi possível a visualização dos septos, sendo necessária a utilização adicional de calcofluor, que tem a propriedade de corar a quitina que delimita os compartimentos das hifas.

TERMOS PARA INDEXAÇÃO: Agaricus blazei, Giemsa, DAPI, Calcofluor, citogenética.

\section{NUCLEUS STAIN OF SPORES AND HIFAS OF Agaricus blazei}

\begin{abstract}
In order to study the nuclear behavior during the sexual cycle of Agaricus blazei, some coloration and fluorescent stain techniques were tested for a method standardization for future cytogenetical works. Among the studied techniques (Schiff reactive, Giemsa, and fluorescent stain - DAPI), the Giemsa and
\end{abstract}

fluorescent DAPI technique provided the best results. With Giemsa stain, it was possible to visualize multinucleate cell compartments. It was not possible to stain compartmental delimitation with DAPI stain, which was possible only with an additional fluorescent stain - calcofluor, which is specific for chitin.

INDEX TERMS: Agaricus blazei, Giemsa, DAPI, calcofluor and cytogenetics.

O cogumelo Agaricus blazei é nativo do Brasil, sendo encontrado naturalmente na região sudoeste de São Paulo. No Brasil, ele passou a ser conhecido como "cogumelo do sol", pelo fato de crescer em campo aberto.

O recente interesse pelo cogumelo Agaricus blazei surgiu pela demanda do mercado japonês, que é o principal comprador. Esse consumo foi despertado graças a estudos no Japão, que permitiram a descoberta e isolamento de substâncias do cogumelo com atividade antitumoral (Kawagishi et al., 1988; Kawagishi et al., 1989; Osaki et al., 1994; Itoh et al., 1994; Higaki et al., 1997; Ito et al., 1997).
Apesar da sua importância e grande perspectiva de utilização, e considerando que o cultivo de Agaricus blazei é relativamente recente no Brasil, observa-se uma carência de estudos genéticos, citogenéticos e fisiológicos básicos e aplicados. Esses estudos serão importantes no futuro para a seleção e/ou desenvolvimento de novas linhagens com maior uniformidade de produção, tamanho, forma e qualidade nutricional do cogumelo. Com isso, objetivou-se com este trabalho a padronização de técnicas de coloração de núcleos de esporos e hifas de Agaricus blazei, para futuros estudos

1. Estudante de doutorado - Ciências dos Alimentos - UNIVERSIDADE FEDERAL DE LAVRAS/UFLA - Caixa Postal 37 -37200-000, Lavras, MG.

2. Professores do Departamento de Biologia/UFLA.

3. Estudante de iniciação científica do curso de Agronomia - Biologia /UFLA. 
citogenéticos dessa espécie, visando à compreensão do comportamento nuclear e seu ciclo sexual.

Para a padronização das técnicas de coloração, foi utilizado um isolado da coleção do Laboratório de Microbiologia da Universidade Federal de Lavras.

Para a coloração de núcleos dos basidiósporos, foram utilizados procedimentos descritos por Robinow (1975), com algumas modificações; para o micélio, utilizou-se a metodologia descrita por Roane (1952), também modificada.

Os esporos para a coloração de núcleos foram obtidos de cogumelos produzidos no Setor de Microbiologia/DBI/UFLA, os quais foram coletados em glicerol a $18 \%$ (suspensão) e conservados a $-20^{\circ} \mathrm{C}$ em tubos "eppendorf". Para o procedimento de coloração dos esporos, a suspensão foi centrifugada por $5 \mathrm{minu}$ tos a $5000 \mathrm{rpm}$, sendo o sobrenadante descartado com ajuda de uma pipeta; em seguida, adicionou-se o fixador metanol na proporção de aproximadamente 3X o volume do "pellet", deixando-se em repouso por 5 minutos. Fez-se nova centrifugação e removeuse o fixador, repetindo-se o procedimento por duas vezes. Ao "pellet" foi adicionado $\mathrm{HCl} 1 \mathrm{~N}$ (3X o volume) para hidrólise e o tubo foi colocado em "banho-maria" por 10 minutos a $60^{\circ} \mathrm{C}$. Após centrifugação, o $\mathrm{HCl}$ foi retirado e os esporos foram ressuspensos em igual volume de água deionizada gelada, sendo lavados por três vezes por centrifugação em água deionizada à temperatura ambiente. Após a última centrifugação, foi adicionado o corante Giemsa ao "pellet" numa concentração de 3:1 (tampão fosfato 0,05 M pH 6,8 / Giemsa) deixando-se a suspensão em repouso por 15 minutos antes da observação dos esporos preparados em lâmina e ao microscópio com objetiva de $40 \mathrm{X}$.

Uma vez corados, os basidiósporos foram medidos com auxílio de uma ocular micrométrica e objetiva de 40 X de um microscópio ótico, sendo, então, realizada a medida latitudinal e longitudinal de 100 basidióporos seguidos da contagem do número de núcleos dos mesmos.

Para as preparações citológicas de micélio, foram utilizadas as metodologias de coloração com Giemsa e com reativo de Schiff (Feulgen) e o fluorocromo DAPI. Hifas reisoladas foram desenvolvidas sobre papelcelofane em placas de Petri com meio básico completo. O papel celofane, sendo poroso, permite que o micélio se desenvolva sem dificuldades, facilitando o procedimento de coloração. As culturas foram mantidas em in- cubadora a $25^{\circ} \mathrm{C}$ até que o micélio cobrisse o celofane. O micélio desenvolvido foi corado na própria membrana de celofane, facilitando o seu manuseio e a montagem das lâminas.

Para a coloração do micélio, foi utilizada a mesma técnica mencionada anteriormente, com algumas adaptações: fixação do micélio em metanol por $5 \mathrm{mi}-$ nutos; hidrólise com $\mathrm{HCl} 1 \mathrm{~N}$ a $60^{\circ} \mathrm{C}$ por $10 \mathrm{minu}-$ tos; lavagem em água deionizada e tampão fosfato por duas vezes; coloração com reativo de Schiff ou Giemsa por 12 e 2 horas, respectivamente.

O fluorocromo DAPI (4'-6-diamidino-2fenilindol) foi utilizado de acordo com a metodologia proposta por Hangland (1996), com modificação, para observação de hifas de Agaricus blazei. Foi testada uma diluição de $1,5 \mu \mathrm{L}$ de DAPI / $500 \mu \mathrm{L}$ tampão fosfato $(0,05 \mathrm{M} \mathrm{pH} \mathrm{6,8).} \mathrm{O} \mathrm{corante} \mathrm{diluído} \mathrm{foi}$ colocado sobre a membrana de celofane com micélio (na ausência de luz) por 5 minutos e, posteriormente, observado utilizando-se microscópio ótico com filtro específico para esses comprimentos de onda, que compreendem entre $358 \mathrm{~nm}$ (excitação) e $461 \mathrm{~nm}$ (emissão). Para observação da parede celular, foi utilizado o fluorocromo calcofluor, na concentração final de $25 \mu \mathrm{M}$ diluída em tampão fosfato $(0,05 \mathrm{M} \mathrm{pH} 6,8)$. Uma alíquota do corante foi colocada sobre o micélio por 5 minutos na total ausência de luz (Hangland, 1996). O material foi visualizado em microscópio ótico com filtros específicos para os comprimentos de onda compreendidos entre $350 \mathrm{~nm}$ (excitação) e $420 \mathrm{~nm}$ (emissão).

A coloração com Giemsa permitiu a visualização dos núcleos em compartimentos bem definidos (Figura 1). Esse corante revelou hifas multinucleadas com 6 ou 8 núcleos, na maioria das células. Bons resultados foram também obtidos com a utilização do DAPI (Figura 2). No entanto, com essa metodologia não foi possível a visualização do septo, o que limita a definição do número de núcleos por compartimento de hifa. A utilização do calcofluor, específico para quitina, tornou possível evidenciar a parede celular do micélio e, conseqüentemente, a delimitação do compartimento celular (Figura 3). Os esporos, também corados com Giemsa, apresentaram-se com média de 4,3 x 6,2 $\mu \mathrm{m}$, sendo a maioria uninucleados.

A técnica de fluorescência, com o DAPI, apesar de mais cara, é extremamente simples e rápida, e poderá ser muito útil para os estudos citogenéticos sobre o $A$ garicus blazei. 


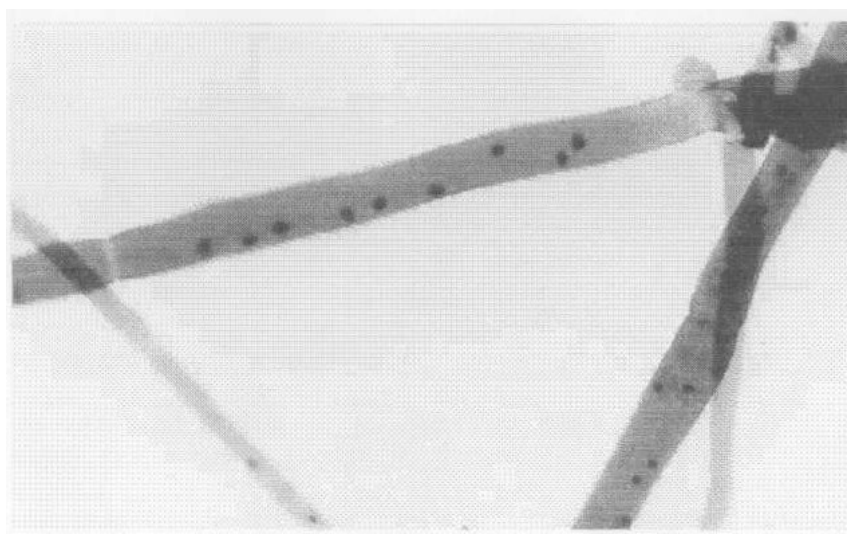

FIGURA 1 - Hifas multinucleadas de Agaricus blazei. Coloração com Giemsa (objetiva de 100 X).

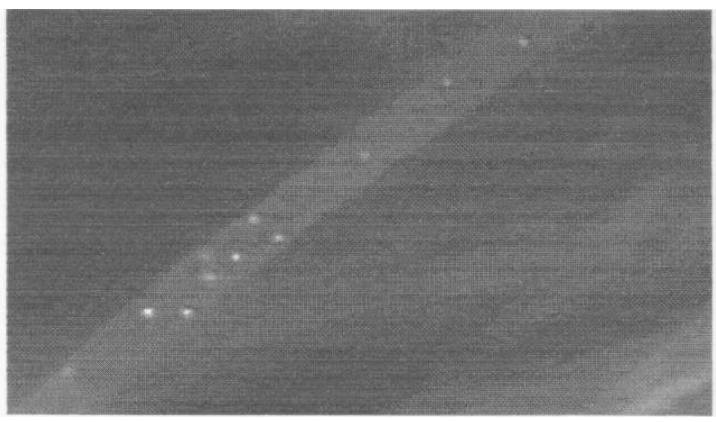

FIGURA 2 - Coloração de hifas de Agaricus blazei com fluorocromo DAPI (objetiva de 100 x).

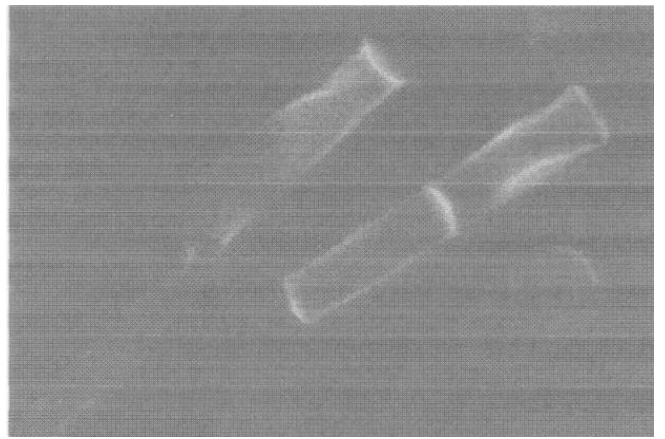

FIGURA 3 - Coloração de septo em hifas de Agaricus blazei com fluorocromo calcofluor (objetiva de 100 x).

\section{REFERÊNCIAS BIBLIOGRÁFICAS}

HANGLAND, R. P. Handbook of fluorescent probes and research chemicals. 6. ed. Eugene: Molecular Probes, 1996.
HIGAKI, M.; EGUCHI, F.; WATANABE, Y. A stable culturing method and pharmacological effects of the Agaricus blazei. Nippon Yakurigaku Zasshi, Kyjiv, v. 110, n. 1, p. 98-103, 1997. Suplemento. 
ITO, H.; SHIMURA, K.; ITOH, H. Antitumor effects of a new polysaccharide-protein complex (ATOM) prepared from Agaricus blazei (Iwade strain 101) "Himematsutake" and its mechanism in tumor-bearing mice. Anticancer Research, [S.1.], v. 17, n. 1A, p. 277-284, 1997.

ITOH, H.; ITO, H.; AMANO, H. Inhibitory action of a (1(6)-beta-D-glucan protein complex (F III-2-b) isolated from Agaricus blazei Muril ("Himematsutake") on Meth A fibrosarcoma-bearing mice and its antitumor mechanism. Japanese Journal of Pharmacology, Kyoto, v. 66, n. 2, p. 265-271, 1994.

KAWAGISHI, H.; INAGAKI, R.; KANAO, T. Fractionation and antitumor activity of the water-insoluble redidue of Agaricus blazei fruiting bodies. Carbohydrate Research, Amsterdam, v. 186, n. 2, p. 267-273, 1989.
KAWAGISHI, H.; NOMURA, A.; YUMEN, T. Isolation and properties of a lectin from the fruiting bodies of Agaricus blazei. Carbohidrate Research, Amsterdam, v. 183, n. 1, p. 150-154, 1988.

OSAKI, Y.; KATO, T.; YAMAMOTO, K. Antimutagenic and bactericidal substances in the fruit body of a Basidiomycete Agaricus blazei, Jun-17. Yakugaku Zasshi, Tokyo, v. 114, n. 12, p. 342-350, 1994.

ROANE, C. W. A method of preparing fungi for cytological studies. Phytopathology, Saint Paul, v. 42, p. 480, 1952. Abstract.

ROBINOW, C. F. The preparation of yeast for light microscopy. In: PRESCOT, T.; DAVID, M. (Eds.). Methods in cell biology. New York: Academic, 1975. v. 11, p. 2-21. 